\title{
Tear of the entire length of the rectum with haemoperitoneum: An unusual cause of the acute abdomen.
}

Dr. Daniel RA Cox MB ChB MRCS ${ }^{\prime}$, Dr. Jonathan Fong MBBS BMedS $c_{i}^{\prime}$, Dr. Krinal Mori MBBS FRACS ${ }^{\prime}$

1. General Surgery Department, Northern Hospital, Melbourne, Australia.

Corresponding author:

Dr. Daniel Cox E daniel.cox@doctors.org.uk T (03) 84058000

c/o The Northern Hospital, Department of Surgery, 185 Cooper St, Epping, VIC 3076. Australia.

Three figures are included in this article (I-III). Figure legends are included at the end of the text.

The corresponding author is not a recipient of a research scholarship.

The authors have no competing interests to declare.

Word Count: 748 (excluding references \& figures).

This is the author manuscript accepted for publication and has undergone full peer review but has not been through the copyediting, typesetting, pagination and proofreading process, which may lead to differences between this version and the Version of Record. Please cite this article as doi: 10.1111/ans.14451

This article is protected by copyright. All rights reserved. 
A 66-year-old gentleman presented to ED after being found unwell at home by a friend. He was initially confused, complaining of severe generalised abdominal pain. The patient became more orientated with resuscitation but was reluctant to give further details regarding the nature of his illness. His past medical history included hypertension, renal colic, myocardial infarction, significant alcohol use but no previous abdominal surgery.

On examination, the patient was alert, tachypnoeic and tachycardic without hypotension or fever. The patient looked unwell; he was groaning and flexing his hips on the bed. His abdominal examination revealed signs of generalised peritonitis with no hernia evident.

His haemoglobin level was $149 \mathrm{~g} / \mathrm{L}$, white cell count of $3.9 \times 10^{9} / \mathrm{L}$ and C-reactive protein value of 2.9 $\mathrm{mg} / \mathrm{L}$. There was new renal impairment, eGFR $52 \mathrm{~mL} / \mathrm{min} / 1.73 \mathrm{~m}^{2}$. Serum lipase, liver function and coagulation studies were normal. Venous blood lactate was $4.8 \mathrm{mmol} / \mathrm{L}$. An erect chest x-ray did not show free sub-phrenic air.

Following resuscitation, a CT of the abdomen and pelvis with oral and IV contrast was ordered (see Figures I and II).

The patient proceeded to the operating theatre; he was positioned in the lithotomy position allowing for greater access to the pelvis in the acute abdomen setting. Pre-operative PR examination identified an anterior rectal tear, its proximal limit was impalpable. Laparoscopy demonstrated large volume haemoperitoneum and thus was followed by a midline laparotomy. At laparotomy four quadrant 
haemoperitoneum was found, mainly consisting of coagulated blood. A large, anterior full thickness rectal tear was identified; the proximal end was at the recto-sigmoid junction extending distally to the peritoneal reflection. No foreign body was found. The edges of the tear were actively bleeding and there was an associated small mesenteric haematoma. Retroperitoneal haematoma was evident but there was minimal faeculant peritoneal contamination. The rectum was mobilised to beyond the level of the prostate; this manoeuvre along with flexible sigmoidoscopy demonstrated the tear extending to 4 cm proximal to the anal verge.

The tear was repaired with interrupted 3'0 polydioxanone sutures (PDS) from an intraperitoneal and trans-anal approach. See Figure III. Following thorough lavage of the abdomen and insertion of a drain to the pelvis, the sigmoid colon was mobilised and divided with a linear cutting stapler. The distal stump was oversewn with 3'0 PDS and a tension-free end colostomy was fashioned.

Colorectal injuries occur due to blunt/penetrating trauma, foreign bodies, sexual behaviour or iatrogenic causes. Whilst there is scant data available regarding their incidence, they are fairly uncommon, accounting for $0.3 \%$ of hollow viscus injuries in blunt trauma.[1]

Rectal injuries can be classified according to location and extent. The rectum is a $15 \mathrm{~cm}$ organ extending from the recto-sigmoid junction to the anus; the anterior and lateral upper two thirds are covered by peritoneum. This important anatomical consideration leads to the subdivision of rectal injuries as 'intra' or 'extra-peritoneal'.[2] The extent of the laceration suggests its propensity for causing devascularisation; lacerations involving $<25 \%$ of the rectal circumference (Rectal Organ Injury Scale I II [3]) are often termed 'non-destructive' compared with more severe 'destructive' injuries.[4] These distinctions, 'destructive vs non-destructive' and 'intra vs extra-peritoneal', weigh significantly on management. 
The modern management of rectal injuries has been inherited from strategies developed in military surgery; the '3 D's - faecal diversion, pre-sacral drainage and distal rectal washout.' [5-6] Recent studies in colonic trauma have found primary repair of non-destructive injuries to have lower complication rates compared with diversion via colostomy.[7] Non-destructive intra-peritoneal rectal injuries can be managed as colonic tears.[8] The degree of faecal contamination, transfusion requirements, quality of tissues and the length of time from injury to operation should be taken into consideration.

There is controversy in the management of non-destructive extra-peritoneal rectal injuries, in particular with regard to the roles of distal rectal washout, faecal diversion and pre-sacral drainage.[4,9] Here the approach should be based upon the accessibility of the injury, associated genitourinary injuries, loss of rectal wall and the degree of pelvic dissection. Trends within the academic literature seem to increasingly advocate more conservative management methods.[10]

This case demonstrates an unusual and challenging cause of the acute abdomen, intra and extraperitoneal rectal injury. Patients in these cases may not offer historical details relating to the cause of the injury or illness; in stable, resuscitated patients a CT of the abdomen and pelvis en route to theatre can prove an invaluable tool. This case highlights the need for a high index of suspicion required for this diagnosis in addition to the diagnostic value of the simple PR examination.

Figure I. Saggital midline section of the CT Abdomen and Pelvis i) Blue arrow indicates free gas retro-rectally in the pre-sacral space, ii) Red arrow indicates an IV contrast 'blush' within the rectum suggestive of active bleeding, iii) Green arrow indicates gas tracking along the retroperitoneum.

Figure II. Axial section of the CT Abdomen and Pelvis, i) Red arrow indicated para-aortic gas, ii) Blue arrow demonstrates free fluid in the abdomen due to baemoperitoneum. 
Figure III. Intra-operative photograph. Orientation: from head looking towards feet. Pelvis displayed, anterior rectal tear with primary suture repair illustrated in mobilised rectum.

\section{REFERENCES}

1. Williams M, Watts D, \& Fakhry S. Colon injury after blunt abdominal trauma: results of the EAST Multi-Institutional Hollow Viscus Injury Study. J Trauma 2003, 55: 906-912

2. McGrath V, Fabian T, Croce M, Minard G \& Pritchard F. Rectal Trauma: Management Based on Anatomic Distinctions. The American Surgeon 1998, 64(12); 1136-1141

3. Moore E, Cogbill T, Malangoni M, Jurkovich G, Champion H, Gennarelli T, McAninch J, Pachter H, Shackford S \& Trafton P. Organ injury scaling, II: Pancreas, duodenum, small bowel, colon, and rectum. J Trauma 1990, 30(11): 1427-1429

4. Gonzalez R, Phelan H, Hassan M, Ellis C, \& Rodning C. Is Fecal Diversion Necessary for Nondestructive Penetrating Extraperitoneal Rectal Injuries? J Trauma 2006, 64(4): 815-819

5. Maxwell, R \& Fabian, T. Current Management of Colon Trauma. World J. Surg 2003, 27: 632-639

6. Steele S, Wolcott K, Mullenix P, Martin M, Sebesta J, Azarow K, Beekley A. Colon and Rectal Injuries During Operation Iraqi Freedom: Are There Any Changing Trends in Management or Outcome? Dis Colon Rectum 2007, 50(6): 870-877

7. Nelson RL \& Singer M. Primary repair for penetrating colon injuries (Review). Cocbrane Database of Systematic Reviews 2003, Issue 3. Art. No.: CD002247

8. Cleary R, Pomerantz R \& Lampman R. Colon and Rectal Injuries. Dis Colon Rectum 2006, 49: 12031222

9. Gonzalez P, Falimirski M, Holevar M. The role of presacral drainage in the management of penetrating rectal injuries. J Trauma 1998, 45: 656 - 661

10. Navsaria P, Graham R, Nicol A. A new approach to extraperitoneal rectal injuries: laparoscopy and diverting loop sigmoid colostomy. J Trauma 2001, 51(3): 532-535 


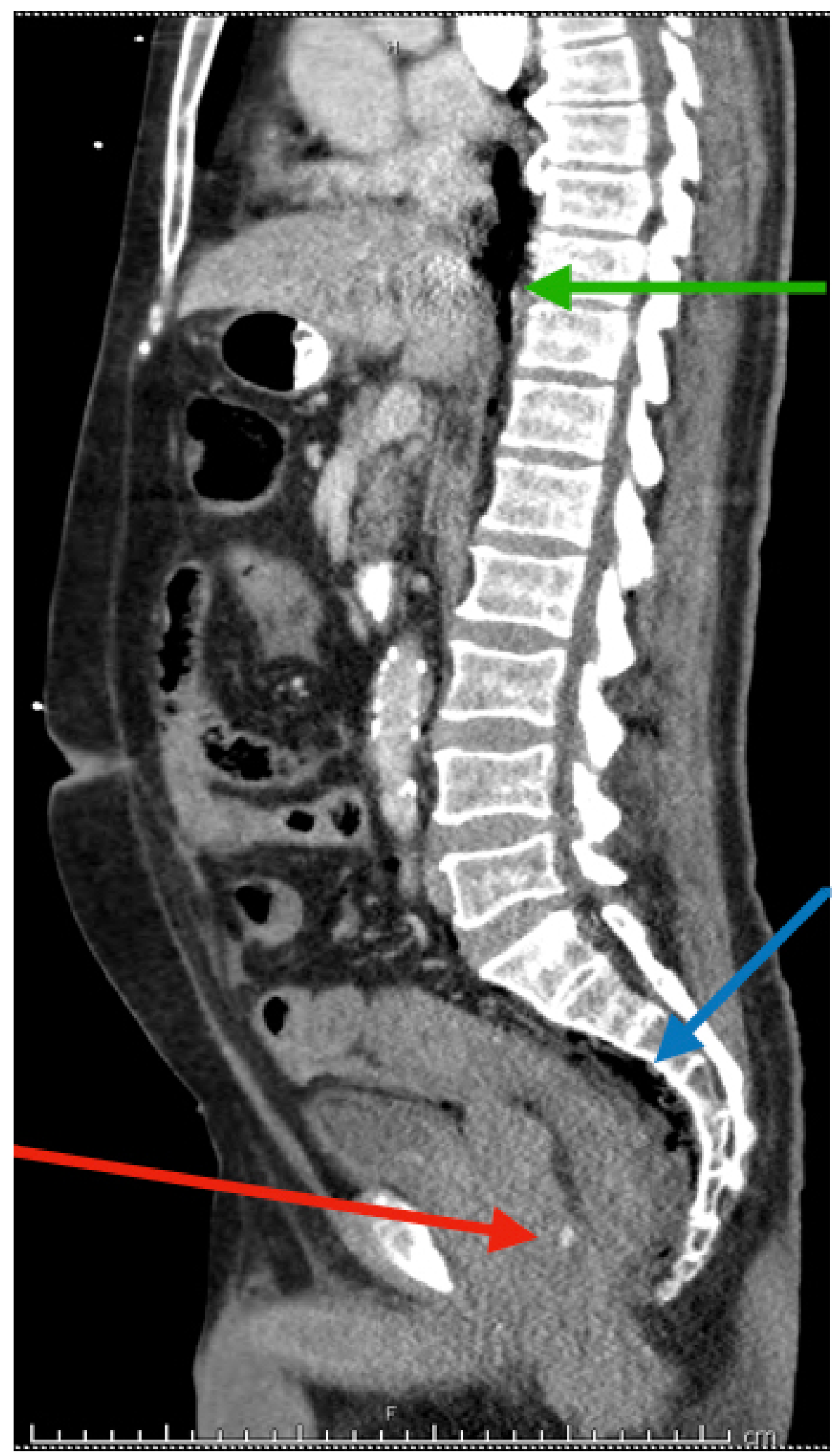

Figure 1.tiff 


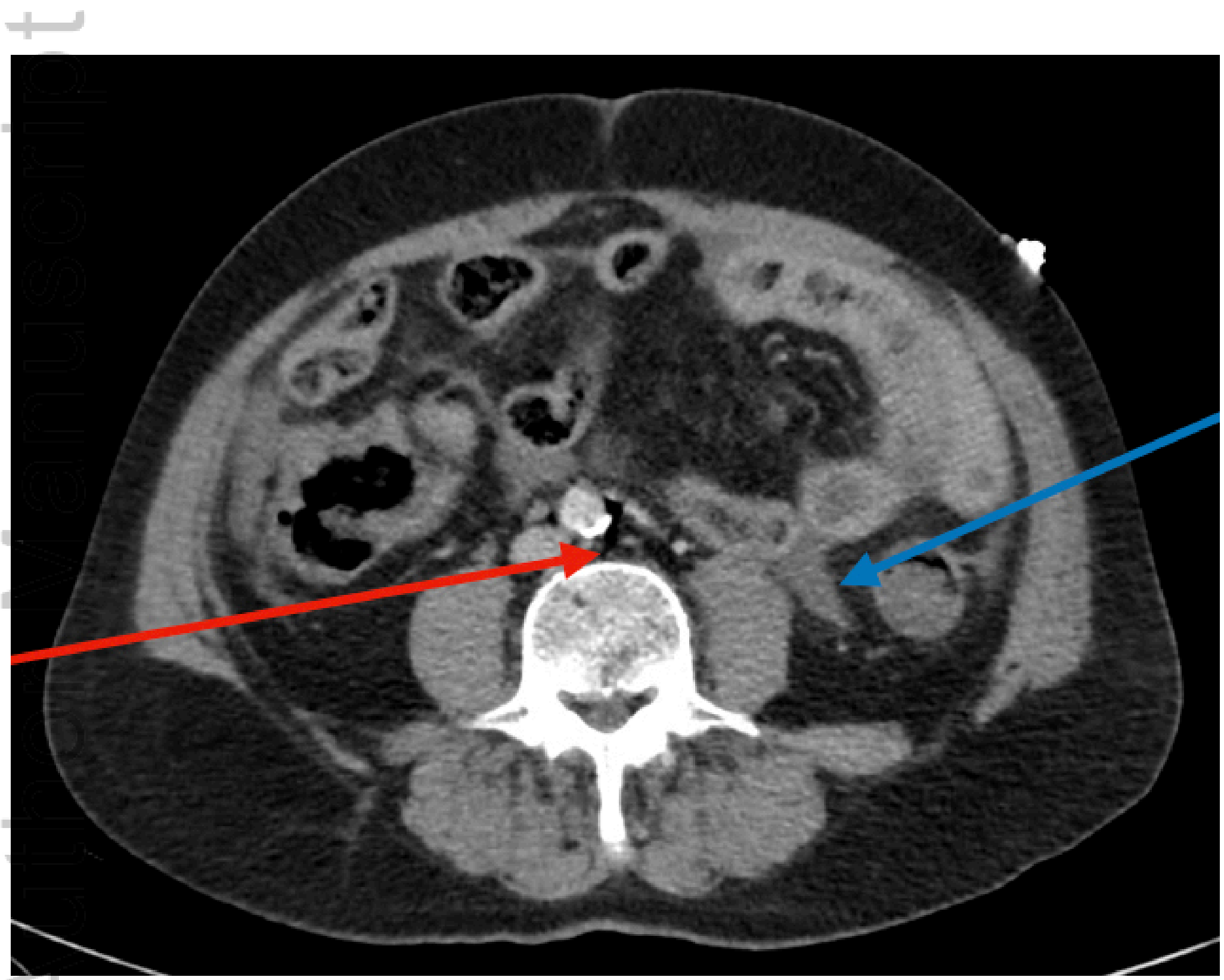

Figure 2.tiff

This article is protected by copyright. All rights reserved. 


\section{University Library}

\section{- M M N E R VA A gateway to Melbourne's research publications}

Minerva Access is the Institutional Repository of The University of Melbourne

Author/s:

Cox, DRA;Fong, J;Mori, $\mathrm{K}$

Title:

Tear of the entire length of the rectum with haemoperitoneum: an unusual cause of the acute abdomen

Date:

2019-07-01

Citation:

Cox, D. R. A., Fong, J. \& Mori, K. (2019). Tear of the entire length of the rectum with haemoperitoneum: an unusual cause of the acute abdomen. ANZ JOURNAL OF SURGERY, 89 (7-8), pp.E331-E332. https://doi.org/10.1111/ans.14451.

Persistent Link:

http://hdl.handle.net/11343/285185 